\title{
In Situ $\mathrm{OH}$ Generation from $\mathrm{O}_{2}^{-}$and $\mathrm{H}_{2} \mathrm{O}_{2}$ Plays a Critical Role in Plasma-Induced Cell Death
}

\author{
Dehui $\mathrm{Xu}^{1}{ }^{*}$, Dingxing Liu ${ }^{1}$, Biqing Wang ${ }^{1}$, Chen Chen ${ }^{1}$, Zeyu Chen ${ }^{1}$, Dong Li ${ }^{1}$, \\ Yanjie Yang ${ }^{1}$, Hailan Chen ${ }^{2}$, Michael G. Kong ${ }^{1,2,3 *}$
}

1 Centre for Plasma Biomedicine, State Key Laboratory of Electrical Insulation and Power Equipment, Xi'an Jiaotong University, Xi'an, China, 2 Frank Reidy Center for Bioelectrics, Old Dominion University, Norfolk, United States of America, 3 Department of Electrical and Computer Engineering, Old Dominion University, Norfolk, United States of America

* dehuixu@ hotmail.com (DX); mkong@ odu.edu (MGK)

\section{G openaccess}

Citation: Xu D, Liu D, Wang B, Chen C, Chen Z, Li $D$, et al. (2015) In Situ $\mathrm{OH}$ Generation from $\mathrm{O}_{2}{ }^{-}$and $\mathrm{H}_{2} \mathrm{O}_{2}$ Plays a Critical Role in Plasma-Induced Cell Death. PLOS ONE 10(6): e0128205. doi:10.1371/ journal.pone.0128205

Academic Editor: Mohammed Yousfi, University Paul Sabatier, FRANCE

Received: December 11, 2014

Accepted: April 24, 2015

Published: June 5, 2015

Copyright: @ $2015 \mathrm{Xu}$ et al. This is an open access article distributed under the terms of the Creative Commons Attribution License, which permits unrestricted use, distribution, and reproduction in any medium, provided the original author and source are credited.

Data Availability Statement: All relevant data are within the paper and its Supporting Information files.

Funding: This research was supported by the National Natural Science Foundation of China (nos. 51307135, 51221005, and 51307134), the Fundamental Research Funds for Central Universities (nos. 08143069 and EIPE 14123), and the Scientific Research Foundation for Returned from Overseas Chinese Scholars, State Education Ministry.

Competing Interests: The authors have declared that no competing interests exist.

\section{Abstract}

Reactive oxygen and nitrogen species produced by cold atmospheric plasma (CAP) are considered to be the most important species for biomedical applications, including cancer treatment. However, it is not known which species exert the greatest biological effects, and the nature of their interactions with tumor cells remains ill-defined. These questions were addressed in the present study by exposing human mesenchymal stromal and LP-1 cells to reactive oxygen and nitrogen species produced by CAP and evaluating cell viability. Superoxide anion $\left(\mathrm{O}_{2}{ }^{-}\right)$and hydrogen peroxide $\left(\mathrm{H}_{2} \mathrm{O}_{2}\right)$ were the two major species present in plasma, but their respective concentrations were not sufficient to cause cell death when used in isolation; however, in the presence of iron, both species enhanced the cell death-inducing effects of plasma. We propose that iron containing proteins in cells catalyze $\mathrm{O}_{2}{ }^{-}$and $\mathrm{H}_{2} \mathrm{O}_{2}$ into the highly reactive $\mathrm{OH}$ radical that can induce cell death. The results demonstrate how reactive species are transferred to liquid and converted into the $\mathrm{OH}$ radical to mediate cytotoxicity and provide mechanistic insight into the molecular mechanisms underlying tumor cell death by plasma treatment.

\section{Introduction}

Cold atmospheric plasma (CAP), an ionized gas, has many biological applications including wound healing, surgical procedures, disinfection, and even cancer treatment[1-5]. Dielectric barrier discharge (DBD) and the plasma jet are two methods for producing CAP; both generate various kinds of reactive oxygen and nitrogen species (ROS and RNS, respectively), including hydroxyl radical $(\mathrm{OH})$, hydrogen peroxide $\left(\mathrm{H}_{2} \mathrm{O}_{2}\right)$, ozone $\left(\mathrm{O}_{3}\right)$, atomic oxygen $(\mathrm{O})$, superoxide anion $\left(\mathrm{O}_{2}{ }^{-}\right)$, nitric oxide $(\mathrm{NO})$, and peroxynitrite anion $\left(\mathrm{ONOO}^{-}\right)[6]$, which are considered as the most biologically relevant components of plasma. Reactive species composition in CAP can be altered by regulating the voltage, frequency, working and feeding gases, and humidity. 
While many studies have shown that CAP is an efficient disinfectant and can also kill normal as well as tumor cells [7-9], it remains unclear which reactive species are chiefly responsible for these biological effects.

Since tissues and cells are immersed in liquid, studies have mostly focused on the interaction of the plasma with a liquid medium. ROS and RNS undergo conversion into different types of reactive species when transferred from gas to liquid phase. Our previous work showed that $\mathrm{O}_{2}{ }^{-}$ and $\mathrm{H}_{2} \mathrm{O}_{2}$ can permeate in distilled water to a greater extent than other species and may interact with cellular components [10]. Computer simulations have shown that $\mathrm{OH}, \mathrm{HO}_{2}$, and $\mathrm{H}_{2} \mathrm{O}_{2}$ can travel deep into a liquid layer to reach biomolecules [11], and that $\mathrm{O}_{2}{ }^{-}, \mathrm{ONOO}^{-}$, $\mathrm{NO}_{3}{ }^{-}, \mathrm{O}_{3}, \mathrm{H}_{2} \mathrm{O}_{2}$, and $\mathrm{HNO}_{\mathrm{X}}$ are the predominant species generated after treatment of a 50$400 \mu \mathrm{M}$ thick water layer with a DBD plasma device [12]. Another study that measured $\mathrm{O}_{2}{ }^{-}$ and $\mathrm{OH}$ using the spin trapping compound CYPMPO and detected the signal by electron spin resonance (ESR) spectrometry showed that $\mathrm{O}_{2}{ }^{-}$and $\mathrm{OH}$ density varied according to plasma jet settings, although the range of concentrations was not reported [13]. OH radicals in $3 \mathrm{ml}$ of aqueous solution produced by atmospheric-pressure He plasma jet measured using terephthalic acid (TA) as a spin trapping compound were present at a concentration of $3.3 \mathrm{uM}$ [14]. The concentration of $\mathrm{OH}$ and $\mathrm{O}_{2}{ }^{-}$in various ionic solutions was about $1-10 \mu \mathrm{M}$ after a 3 min Ar plasma treatment, as measured by ESR [15]. However, there is no information about whether these species can interact with biomolecules in liquid medium during plasma treatment.

The present study investigated this question in human mesenchymal stromal cells (MSCs) and LP-1 myeloma tumor cells exposed to CAP generated by a plasma jet. The results demonstrate that $\mathrm{O}_{2}{ }^{-}$and $\mathrm{H}_{2} \mathrm{O}_{2}$ are the two major reactive species in liquid but are present at concentrations that are insufficient to cause cell death; this was ultimately induced by the $\mathrm{OH}$ radical generated in situ upon exposure of cells to $\mathrm{O}_{2}{ }^{-}$and $\mathrm{H}_{2} \mathrm{O}_{2}$ in the plasma. These findings provide insight into the molecular mechanisms underlying plasma-induced tumor cell death, and may also provide a basis for generating a more powerful plasma enriched with particular reactive species for biological applications such as cancer treatment.

\section{Materials and Methods}

\section{Plasma generation and characterization}

CAP was generated by a plasma jet system consisting of a $1 \mathrm{~mm}$ powered electrode enclosed in a quartz tube, with a grounded outer electrode wrapped around a $6.0 \mathrm{~mm}$ diameter dielectric tube (Fig 1). The system also included a gas flow controller, high-voltage power supply, oscilloscope, and plasma jet. A gas flow of $2 \mathrm{slm}$ for $\mathrm{He} / \mathrm{Ar}$ was used at voltages of $10 \mathrm{kHz} / 8 \mathrm{kV}$ for $\mathrm{He}$ and $10 \mathrm{kHz} / 10 \mathrm{kV}$ for Ar. The detailed experimental setup is shown in S1 Fig.

\section{Cell culture}

Human MSCs and LP-1 cells [16] were cultured in Roswell Park Memorial Institute (RPMI) 1640 medium supplemented with $10 \%$ fetal calf serum, $100 \mathrm{U} / \mathrm{ml}$ penicillin, $50 \mu \mathrm{g} / \mathrm{ml}$ streptomycin, and $2 \mathrm{mM}$ L-glutamine (all from Hyclone, Logan, UT, USA), in an atmosphere of 5\% $\mathrm{CO}_{2}$ at $37^{\circ} \mathrm{C}$. MSCs were trypsinized and refreshed weekly and only cells from nine or fewer passages were used in the experiments.

\section{Plasma treatment}

Normally, cells were cultured in a 24 well plate in $300 \mathrm{ul} \mathrm{RPMI} 1640$ medium at a concentration of $2 \times 10^{5}$ cells. For cell viability assay, MSC cells were cultured in a 96 well plate in $100 \mathrm{ul}$ 


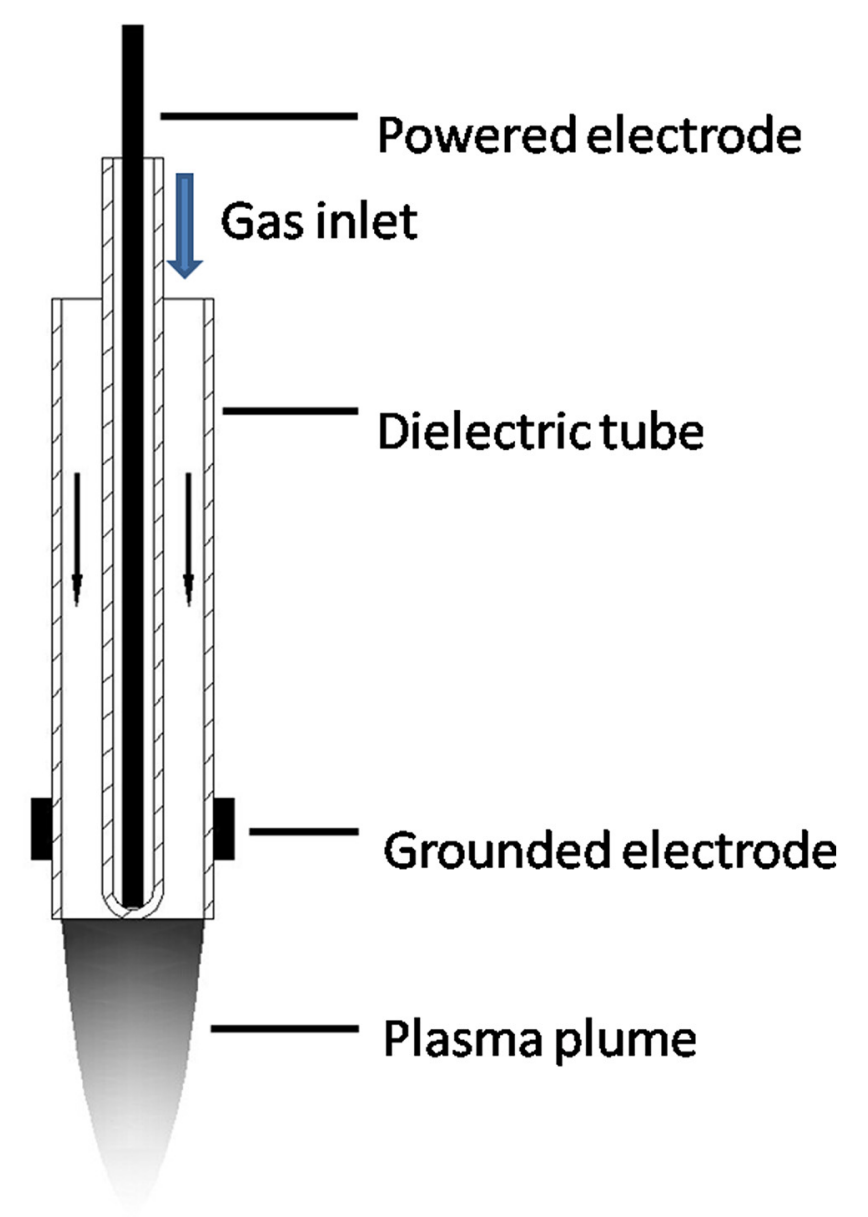

Fig 1. Schematic illustration of the plasma jet used in this study.

doi:10.1371/journal.pone.0128205.g001

RPMI1640 medium at a concentration of $1 \times 10^{5}$ cells. Luminescence was measured $24 \mathrm{~h}$ after plasma treatment by directly adding 100 ul of Cell-Titer-Glo reagent into the cells, which could avoid trypsinization of MSC cells and losing some un-adherent cells after plasma treatment.

\section{Reagents}

Radical scavengers were purchased from Sigma (St. Louis, MO, USA) [17]. The scavengers used were as follows: sodium pyruvate $(10 \mathrm{mM})$ for $\mathrm{H}_{2} \mathrm{O}_{2}$ [18]; mannitol (50 mM) for $\mathrm{OH}$ [18]; carboxy-PTIO $(100 \mu \mathrm{M})$ for NO [18]; trolox $(100 \mu \mathrm{M})$ for peroxyl radical (ROO•) [19]; uric acid $(100 \mu \mathrm{M})$ for $\mathrm{O}_{3}$ and $\mathrm{ONOO}^{-}[18,20]$; sodium azide $(1 \mathrm{mM})$ for singlet oxygen $\left({ }^{1} \mathrm{O}_{2}\right)$ [18]; and tiron $(10 \mathrm{mM})$ for $\mathrm{O}_{2}^{-}$[21]. These are specific scavengers with little cross-reactivity to other ROS and are widely used for investigating the function of particular ROS [17]. Fe(III)ethylenediaminetetraacetic acid (EDTA; $1 \mu \mathrm{M}$ ) was purchased from Tokyo Chemical Industry Co. Ltd. (Tokyo, Japan). Apo- and holo-ferritin were purchased from MP Biomedicals (Santa Ana, CA, USA).

\section{Cell viability assay}

MSCs were seeded in RPMI1640 medium in 96 well optical plates at a concentration of $10^{5}$ cells $/ 100$ ul well. After plasma treatment for $30 \mathrm{~s}$, or 1 or $2 \mathrm{~min}$, cells were grown for further 
$24 \mathrm{~h}$. Cell viability was assessed using the CellTiter-Glo assay (Promega, Madison, WI, USA) according to the manufacturer's instructions. CellTiter-Glo measures luminescence to quantify the level of ATP, which is positively correlated with cell viability. Briefly, $100 \mathrm{ul}$ reagent were added to $100 \mathrm{ul}$ cells and the mixture was lysed by placing on an orbital shaker for $2 \mathrm{~min}$, followed by a $10 \mathrm{~min}$ incubation at room temperature. Luminescence was measured with a microplate reader (Varioskan Flash; Thermo Scientific, Waltham, MA, USA).

\section{Observation of morphological changes by microscopy}

Cell morphological changes after plasma treatment were examined and imaged using an IX51 inverted phase contrast light microscope (Olympus, Tokyo, Japan). MSCs were normally adherent, with a polygonal shape; dying cells became shrunken and rounded, and detached from the plate.

\section{Flow cytometry for analysis of apoptosis}

Cells were washed twice with Dulbecco's Phosphate-Buffered Saline without calcium and magnesium $\left(\mathrm{Ca}^{2+} / \mathrm{Mg}^{2+}\right.$-free DPBS; Corning, NY, USA) containing $0.5 \%$ bovine serum albumin and resuspended in $50 \mu \mathrm{l}$ of $1 \times$ binding buffer $(0.01 \mathrm{M}$ Hepes/NaOH $(\mathrm{pH} 7.4), 0.14 \mathrm{M} \mathrm{NaCl}$ and $2.5 \mathrm{mM} \mathrm{CaCl}_{2}$ ) with $2.0 \mu \mathrm{l}$ annexin $\mathrm{V}$-fluorescein isothiocyanate (FITC) and $2.0 \mathrm{ul}$ propidium iodide (PI) (Becton Dickinson, Franklin Lakes, NJ, USA) and incubated in the dark at room temperature for $15 \mathrm{~min}$. An additional $400 \mu \mathrm{l}$ of binding buffer were added and fluorescence was analyzed on an Accuri C6 flow cytometry (Becton Dickinson).

\section{$\mathrm{H}_{2} \mathrm{O}_{2}$ assay}

$\mathrm{H}_{2} \mathrm{O}_{2}$ level was measured using the Amplex Red Hydrogen Peroxide Assay Kit (Invitrogen, Carlsbad, CA, USA). A working solution of $100 \mu \mathrm{M}$ Amplex Red reagent and $0.2 \mathrm{U} / \mathrm{ml}$ horseradish peroxidase (HRP) was prepared beforehand. $\mathrm{An}_{2} \mathrm{H}_{2}$ standard curve was generated with freshly prepared $\mathrm{H}_{2} \mathrm{O}_{2}$ (Invitrogen) concentrations ranging from 0 to $40 \mu \mathrm{M}$. A $50 \mu \mathrm{l}$ volume of Amplex Red reagent/HRP working solution was added to each microplate well containing standards, controls, and samples (in a volume of $50 \mu \mathrm{l}$ ). The mixture was incubated at room temperature for $30 \mathrm{~min}$ while shielded from light. The $\mathrm{H}_{2} \mathrm{O}_{2}$ concentration was detected using a microplate reader (Thermo Scientific Varioskan Flash) at excitation and emission wavelengths of $530-560 \mathrm{~nm}$ and $\sim 590 \mathrm{~nm}$, respectively.

\section{Western blotting}

Cell pellets were lysed in lysis buffer containing $50 \mathrm{mM}$ Tris, $150 \mathrm{mM} \mathrm{NaCl}, 1 \%$ Nonidet P40, and $0.25 \%$ sodium deoxycholate. Cell debris was removed by centrifugation for $5 \mathrm{~min}$ at $14,000 \mathrm{rpm}$ before sample buffer was added. After boiling, samples were separated by sodium dodecyl sulfate-polyacrylamide gel electrophoresis (SDS-PAGE) and transferred to polyvinylidene difluoride membranes (Bio-Rad, Hercules, CA, USA), which were blocked with PBS containing $5 \%$ low-fat milk and $0.1 \%$ Tween 20 . Membranes were probed with antibodies against human ferritin heavy chain (FTH1) (1:1000) and $\beta$-actin (1:1000) (Cell Signaling Technology, Danvers, MA, USA). Membranes were washed with PBS containing $0.1 \%$ Tween 20 (PBST) for 30 min and then incubated with HRP-conjugated goat anti-rabbit IgG (1:2000 for FTHI) and anti-mouse $\operatorname{IgG}(1: 2000$ for $\beta$-actin) for $30 \mathrm{~min}$ at room temperature. Membranes were washed in PBST and imaged using a ChemiDoc-It 510 system (UVP, Upland, CA, USA). 


\section{Coomassie Blue staining}

Holo- and apo-transferrin were dissolved at concentrations of $0.1 \mathrm{mg} / \mathrm{ml}$ in $300 \mu \mathrm{l} \mathrm{Ca}{ }^{2+} / \mathrm{Mg}^{2+}$-free DPBS and treated with Ar plasma for 2 or $8 \mathrm{~min}$. Buffer was added and the samples were boiled, then separated by $12 \%$ SDS-PAGE and stained with Coomassie Blue for $20 \mathrm{~min}$, followed by destaining for $1 \mathrm{~h}$.

\section{Transfection of MSCs with pre-microRNA (miR)-200b}

MSCs were cultured in a 6 well plate at $5 \times 10^{5}$ cells/well in $2 \mathrm{ml}$ RPMI1640 medium. Cells were transfected with pre-miR-200b (50 nM) using Lipofectamine 2000 (both from Invitrogen) according to the manufacturer's instructions. Cells transfected with scrambled RNA oligonucleotide served as a control. Cells were harvested $48 \mathrm{~h}$ after transfection for western blot analysis. For the cell viability assay, cells were cultured in a 96 well plate at $10^{5}$ cells/well in $100 \mathrm{ul}$ RPMI1640 medium and transfected with pre-miR-200b (50 nM) and scrambled control miRNA. After $24 \mathrm{~h}$, cells were treated with Ar plasma for $20 \mathrm{~s}$ and cell viability was assessed with the CellTiter-Glo assay $24 \mathrm{~h}$ and $48 \mathrm{~h}$ later.

\section{Statistical analysis}

All experimental conditions were prepared in triplicate and experiments were repeated at least three times. Data are presented as mean \pm SD. Differences between groups were evaluated using the Mann-Whitney $\mathrm{U}$ test. $\mathrm{P}<0.05$ was considered statistically significant.

\section{Results and Discussion}

A $2 \mathrm{slm}$ gas flow was used to produce CAP by plasma jet. Two types of plasma- $\mathrm{He}+\mathrm{H}_{2} \mathrm{O}$ and $\mathrm{Ar}$-were tested. $\mathrm{He}+\mathrm{H}_{2} \mathrm{O}$ plasma was produced at $10 \mathrm{kHz} / 8 \mathrm{kV}$ with $1 \% \mathrm{H}_{2} \mathrm{O}$ in $\mathrm{He}$ gas $(1.5$ slm dry He gas with $0.5 \mathrm{slm}$ humid He gas), while Ar plasma was produced at $10 \mathrm{kHz} / 10 \mathrm{kV}$. The distance between the plasma jet and liquid was fixed at $1.5 \mathrm{~cm}$. The $2 \mathrm{slm}$ of plasma gas flow resulted in slight evaporation of the $300 \mu$ volume of medium in the 24 well plate, which was reduced by about $5 \mu \mathrm{l}$ after plasma treatment for $2 \mathrm{~min}$ (data not shown). Next, MSCs cultured in 100 ul RPMI1640 medium in a 96 well plate were treated with plasma for various times $(10,30,60$, and $120 \mathrm{~s})$ and cell viability was measured after $24 \mathrm{~h}$. $\mathrm{He}+\mathrm{H}_{2} \mathrm{O}$ and Ar plasma induced MSC apoptosis in a time-dependent manner (Fig 2A); this was accompanied by morphological changes after 120 s of plasma treatment, with cells gradually shrinking and becoming rounded (Fig 2B). A time series detection by flow cytometry of annexin-V and PIstained cells showed that the number of annexin- $\mathrm{V}^{+}$cells gradually increased over $24 \mathrm{~h}$ following a 60 s Ar plasma treatment (Fig 2C).

To evaluate the interaction between plasma and liquid, a computer simulation was used to calculate the distribution of different radicals in liquid water with the following set of equations.

$$
\left\{\begin{array}{c}
\frac{\partial c_{i}}{\partial t}+\frac{\partial \Gamma_{i}}{\partial x}=\frac{\partial c_{i}}{\partial t}-\frac{\partial}{\partial x}\left(D_{i, a q} \frac{\partial c_{i}}{\partial x}\right)=\sum R_{i}(t) \\
\frac{\partial c_{j}}{\partial t}+\frac{\partial \Gamma_{j}}{\partial x}=\frac{\partial c_{j}}{\partial t}-\frac{\partial}{\partial x}\left(D_{j, a q} \frac{\partial c_{j}}{\partial x} \mp E_{x} c_{j} U_{j}\right)=\sum R_{j}(t) \\
\frac{\partial^{2} V}{\partial x^{2}}=-\frac{\sum \rho_{n e t}}{\varepsilon_{H_{2} O}}, E=-\frac{\partial V}{\partial x}
\end{array}\right.
$$

The boundary conditions and parameters of this model were described in our previous work [22]. Among the variety of radicals in the plasma gas phase, certain species were 


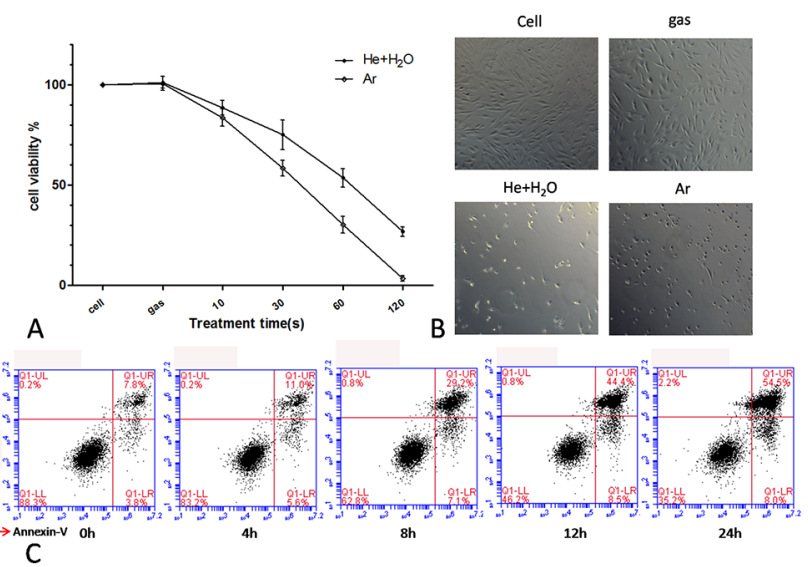

Fig 2. Cell death induced by $\mathrm{He}+\mathrm{H}_{2} \mathrm{O}$ and Ar plasma. (A) Viability of MSCs $24 \mathrm{~h}$ after treatment with plasma for the indicated times. (B) Morphological changes in MSCs $24 \mathrm{~h}$ after treatment with plasma for 120 s. Ar gas flow without discharge was used as control. (C) Time course of MSC cell apoptosis by flow cytometry after Ar plasma treatment for $60 \mathrm{~s}$.

doi:10.1371/journal.pone.0128205.g002

transferred further than others: while most disappeared or were converted into other species at a depth of $1 \mathrm{~mm}, \mathrm{O}_{2}{ }^{-}$and $\mathrm{H}_{2} \mathrm{O}_{2}$ reached depths of up to $2 \mathrm{~mm}$ (Fig 3A).

When scavengers for particular species were added in order to exclude the effect of the particular ROS and RNS generated during the process of plasma treatment, we first confirmed that these scavengers are non-toxic to cells at the working concentrations used in the assays (data not shown). The results showed that depletion of $\mathrm{O}_{2}{ }^{-}$or $\mathrm{H}_{2} \mathrm{O}_{2}$, but not of other species such as $\mathrm{OH}, \mathrm{NO}, \mathrm{ROO} \cdot \mathrm{O}^{3}, \mathrm{ONOO}^{-}$, or ${ }^{1} \mathrm{O}_{2}$, annihilated the effects of plasma treatment, as seen by the changes in cell viability (Fig 3B) and cell morphology (Fig 3C). These results indicate that $\mathrm{O}_{2}{ }^{-}$and $\mathrm{H}_{2} \mathrm{O}_{2}$ were the predominant species for induction of apoptosis generated by plasma treatment. Moreover, when 500-600 $\mu \mathrm{l}$ of culture medium were added to each well (yielding a depth of about $3 \mathrm{~mm}$ in a 24 well plate), the plasma treatment induced little or no cell death (data not shown).
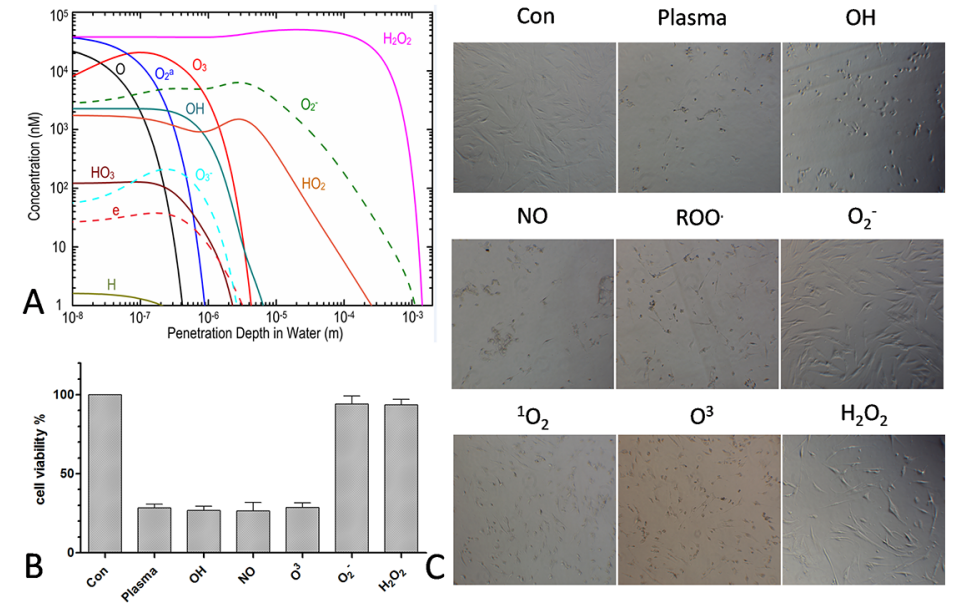

Fig 3. Plasma-induced cell death is reversed by reactive species scavengers. (A) Computer simulation of the distribution of various species in liquid. (B, C) MSC viability and morphological changes $24 \mathrm{~h}$ after treatment with $\mathrm{He}+\mathrm{H}_{2} \mathrm{O}$ plasma for $60 \mathrm{~s}$ in the presence of various scavengers.

doi:10.1371/journal.pone.0128205.g003 

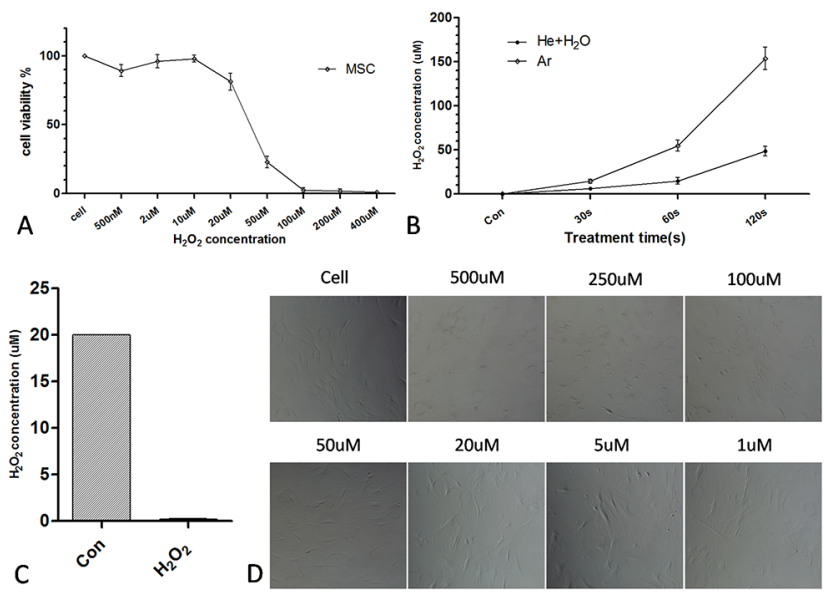

Fig 4. Contribution of $\mathrm{H}_{2} \mathrm{O}_{2}$ to plasma-induced cell death. (A) Viability of MSCs treated with different concentrations of $\mathrm{H}_{2} \mathrm{O}_{2}$ for $24 \mathrm{~h}$. (B) $\mathrm{H}_{2} \mathrm{O}_{2}$ concentration measured by the hydrogen peroxide assay after $\mathrm{He}$ $+\mathrm{H}_{2} \mathrm{O}$ and Ar plasma treatment for the indicated times. (C) $\mathrm{H}_{2} \mathrm{O}_{2}$ concentration measured relative to the control (20 $\mu \mathrm{M} \mathrm{H}_{2} \mathrm{O}_{2}$ solution) after adding $\mathrm{H}_{2} \mathrm{O}_{2}$ scavenger. (D) Morphological changes in MSCs treated with indicated $\mathrm{H}_{2} \mathrm{O}_{2}$ concentrations for $24 \mathrm{~h}$.

doi:10.1371/journal.pone.0128205.g004

To determine which of $\mathrm{O}_{2}{ }^{-}$or $\mathrm{H}_{2} \mathrm{O}_{2}$ induces the greatest biological effect, cells treated with $\mathrm{H}_{2} \mathrm{O}_{2}$ with or without plasma were compared. $\mathrm{H}_{2} \mathrm{O}_{2}$ alone induced cell death at concentrations of 50-100 $\mu \mathrm{M}$ (Fig 4A). Only $\mathrm{H}_{2} \mathrm{O}_{2}$ concentrations $>100 \mu \mathrm{M}$ caused morphological changes after $24 \mathrm{~h}$ (Fig $4 \mathrm{D}$ ). $\mathrm{H}_{2} \mathrm{O}_{2}$ production was then measured after plasma treatment for different times. The concentration of $\mathrm{H}_{2} \mathrm{O}_{2}$ after a $60 \mathrm{~s} \mathrm{He}+\mathrm{H}_{2} \mathrm{O}$ plasma treatment was $<20 \mu \mathrm{M}$, suggesting that the $\mathrm{H}_{2} \mathrm{O}_{2}$ radical in itself is insufficient for inducing cell death (Fig 4B); $\mathrm{H}_{2} \mathrm{O}_{2}$ was completely abolished by treatment with an $\mathrm{H}_{2} \mathrm{O}_{2}$ scavenger, showing that scavenger could be a useful method to determine the effect of $\mathrm{H}_{2} \mathrm{O}_{2}$ (Fig 4C).

Because there is no $\mathrm{O}_{2}{ }^{-}$reagent, cells treated with $\mathrm{O}_{2}{ }^{-}$with or without plasma could not be compared. We therefore attempted to separate $\mathrm{O}_{2}{ }^{-}$from $\mathrm{H}_{2} \mathrm{O}_{2}$ by applying a bias voltage, since $\mathrm{O}_{2}{ }^{-}$is electronegative and is attracted by a positive voltage, as summarized in Fig 5 .

The basic equations were the same as those previously described. Given the dielectric layer at the bottom, the charge conservation equation was included to calculate the effect of charge accumulation.

$$
\left\{\begin{array}{l}
\frac{\partial \rho_{\text {dish }}}{\partial t}+\nabla \bullet J_{d i s h}=0 \\
J_{d i s h}=\sigma_{d i s h} E
\end{array}\right.
$$

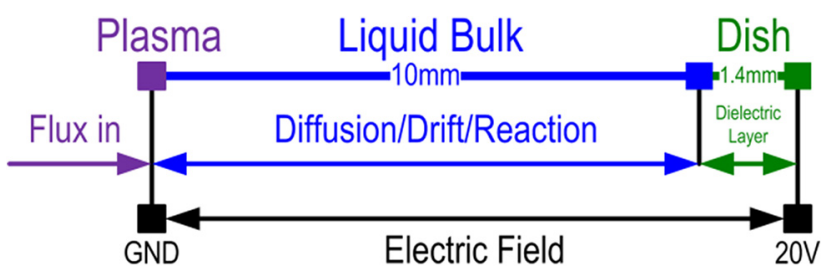

Fig 5. A schematic diagram for applying a bias voltage.

doi:10.1371/journal.pone.0128205.g005 
The Poisson equation for the dielectric area was also applied.

$$
\frac{\partial^{2} V}{\partial x^{2}}=\left\{\begin{array}{l}
-\frac{\sum \rho_{n e t}}{\varepsilon_{H_{2} O}} \\
-\frac{\rho_{\text {dish }}}{\varepsilon_{\text {dish }}}
\end{array}, E=-\frac{\partial V}{\partial x}\right.
$$

The simulation showed that the penetration depth of $\mathrm{O}_{2}{ }^{-}$was increased by applying $\mathrm{a}+20$ $\mathrm{V}$ bias voltage, while that of $\mathrm{H}_{2} \mathrm{O}_{2}$ also increased slightly (Fig 6A). As a neutral species, $\mathrm{H}_{2} \mathrm{O}_{2}$ should theoretically be unaffected by a bias voltage. The slight increase observed for $\mathrm{H}_{2} \mathrm{O}_{2}$ was presumed to be caused by $\mathrm{O}_{2}{ }^{-}$. As stated in our previous work [22], only $\mathrm{H}_{2} \mathrm{O}_{2}, \mathrm{HO}_{2}$, and $\mathrm{O}_{2}{ }^{-}$ can exist at a depth of $1 \mathrm{~mm}$; the reactions are as follows.

$$
\begin{gathered}
\mathrm{O}_{2}^{-}+\mathrm{H}^{+} \stackrel{97.9 \%}{\longrightarrow} \mathrm{HO}_{2} \\
\mathrm{O}_{2}^{-}+\mathrm{H}_{2} \mathrm{O} \stackrel{2.28 \%}{>} \mathrm{HO}_{2}+\mathrm{OH}^{-} \\
2 \mathrm{HO}_{2} \stackrel{86.2 \%}{\longrightarrow} \mathrm{H}_{2} \mathrm{O}_{2}+\mathrm{O}_{2}
\end{gathered}
$$

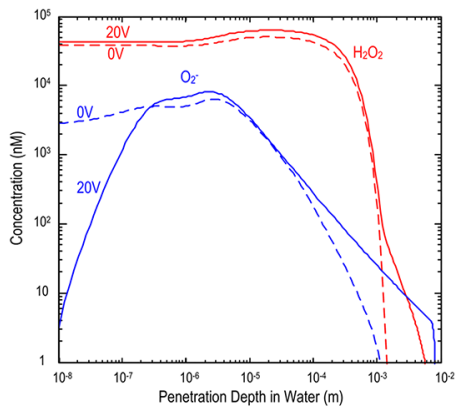

A

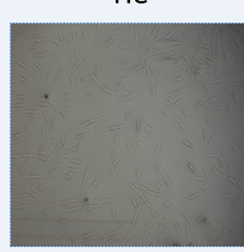

$\operatorname{Ar}$
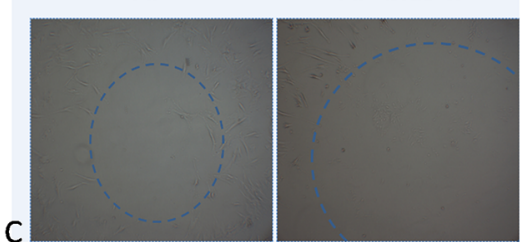

B

He+bias v.

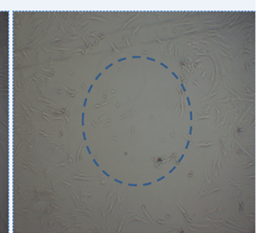

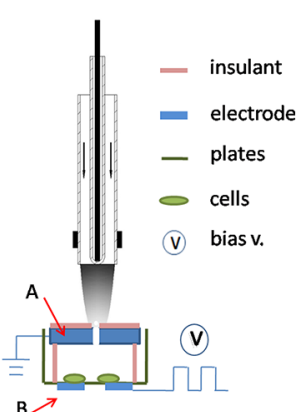
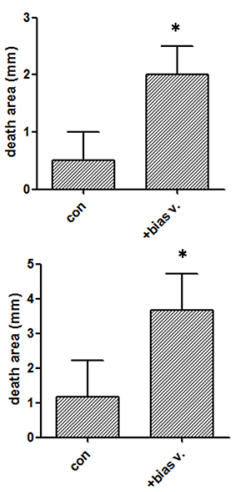

Fig 6. Contribution of $\mathrm{O} 2-$ and $\mathrm{H}_{2} \mathrm{O}_{2}$ in plasma-induced cell death. (A) The $\mathrm{O}_{2}{ }^{-}$and $\mathrm{H}_{2} \mathrm{O}_{2}$ distribution in liquid determined after applying $\mathrm{a}+20 \mathrm{~V}$ bias voltage by computer simulation. Broken and the solid lines represent concentrations of $\mathrm{O}_{2}^{-}$and $\mathrm{H}_{2} \mathrm{O}_{2}$, before and after voltage application, respectively,. (B) Experimental setup for application of bias voltage. $A$ and $B$ indicate cover node and bias voltage, respectively. (C) MSCs treated with $\mathrm{He}+\mathrm{H}_{2} \mathrm{O}$ or Ar plasma for $60 \mathrm{~s}$ while applying a $+20 \mathrm{~V}$ bias voltage. The histogram displays the diameter of the cell death area relative to the control. ${ }^{*} \mathrm{P}<0.05$.

doi:10.1371/journal.pone.0128205.g006 
Applying a bias voltage increased the penetration depth of $\mathrm{O}_{2}{ }^{-}$, which may have been partly converted to $\mathrm{H}_{2} \mathrm{O}_{2}$, thereby increasing its concentration.

The experimental setup for testing the above simulation is shown in Fig 6B. Several sizes for the cover (A) and bias voltage node (B) were tested, and diameters of 1.5 and $5 \mathrm{~mm}$, respectively, were ultimately used. Based on the simulation, the penetration of $\mathrm{O}_{2}{ }^{-}$was predicted to be deeper and cover a broader area. Indeed, after applying a bias voltage of $+20 \mathrm{~V}$, the area of cell death cell was increased significantly by a $60 \mathrm{~s} \mathrm{He}+\mathrm{H}_{2} \mathrm{O}$ or Ar plasma treatment (Fig 6C). Furthermore, to exclude the effect of $\mathrm{H}_{2} \mathrm{O}_{2}$, a scavenger was added to the medium before the bias voltage was applied. Although $\mathrm{O}_{2}{ }^{-}$penetration was still deeper and covered a larger area, in the absence of $\mathrm{H}_{2} \mathrm{O}_{2}$, the area of cell death was unchanged (data not shown). These results demonstrate that $\mathrm{H}_{2} \mathrm{O}_{2}$ and $\mathrm{O}_{2}{ }^{-}$are the major reactive species that induce cell death. However, each species alone was insufficient to produce this effect, suggesting that a synergistic interaction occurs.

The suggestion of $\mathrm{OH}$ radical production being catalyzed by iron [23] has been experimentally validated by the discovery of several Fenton-like reactions [24-26]. In the iron-catalyzed Haber-Weiss reaction, $\mathrm{OH}$ is produced from $\mathrm{H}_{2} \mathrm{O}_{2}$ and $\mathrm{O}_{2}{ }^{-}$radicals [26].

$$
\mathrm{H}_{2} \mathrm{O}_{2}+\mathrm{O}_{2}^{-} \stackrel{\mathrm{Fe}^{2+} / \mathrm{Fe}^{3+}}{\longrightarrow} \mathrm{OH}^{-}+\cdot \mathrm{OH}+\mathrm{O}_{2}
$$

It is now widely acknowledged that the Haber-Weiss reaction does not occur in the absence of metal catalysts [27]; the reaction has been directly observed in the gas phase in the presence of iron [28].

We set out to determine whether the Haber-Weiss reaction occurs in a plasma-treated cell system. Findings from previous studies suggested that plasma treatment could provide both $\mathrm{H}_{2} \mathrm{O}_{2}$ and $\mathrm{O}_{2}{ }^{-}$species at $\mu \mathrm{M}$ concentrations. Cells typically express several iron proteins such as ferroportin [29, 30], lactoferrin receptor [31], transferrin [32, 33], divalent metal transporter 1 [34, 35], and ferritin [36,37], among others. These proteins could conceivably catalyze $\mathrm{H}_{2} \mathrm{O}_{2}$ and $\mathrm{O}_{2}{ }^{-}$radicals into a highly reactive $\mathrm{OH}$ radical that has more potent biological effects.

To test this hypothesis, transferrin-which is known as holo- or apo-transferrin depending on whether it is or is not bound to iron, respectively-was examined. Both forms of the protein $(0.1 \mathrm{mg} / \mathrm{ml}$ in $300 \mu \mathrm{l}$ PBS solution) were treated with Ar plasma and protein degradation was assessed by gel electrophoresis. After an $8 \mathrm{~min}$ plasma treatment, holo- but not apo-transferrin showed significant degradation (Fig 7A), suggesting that the presence of iron resulted in the catalysis of the Haber-Weiss reaction, thereby enhancing the effects of the plasma. It has been reported that the superoxide anion may also induces the release of ferrous iron from transferrin [38], further facilitating the Haber-Weiss reaction and consequent $\mathrm{OH}$ formation. Ferritin expression was then knocked down with miR-200b [39] and cells were examined for their sensitivity to plasma treatment; the sequences of miR-200b and the complementary site in the FTH1 gene are shown in Fig 7B. Cell viability was decreased by knockdown of FTH1 gene expression (Fig 7C). After $24 \mathrm{~h}$ of transfection, cells were treated with $\mathrm{Ar}$ or $\mathrm{He}+\mathrm{H}_{2} \mathrm{O}$ plasma (data not shown) for $20 \mathrm{~s}$ followed by a $24 \mathrm{~h}$ incubation. The downregulation of ferritin expression by miR-200b as compared to the control transfection was confirmed by western blotting (Fig 7D), and was associated with a decrease in cell sensitivity to Ar plasma treatment (Fig 7E). These data suggest that iron proteins act as catalysts that transform $\mathrm{H}_{2} \mathrm{O}_{2}$ and $\mathrm{O}_{2}{ }^{-}$into the highly reactive $\mathrm{OH}$ radical, which then induces cell death.

Iron was added in the form of $\mathrm{Fe}(\mathrm{III})$-EDTA to the plasma-treated cell system to enhance $\mathrm{OH}$ production and consequently cell death. To circumvent the possibility that the penetration of iron-catalyzed $\mathrm{OH}$ would not be sufficiently deep to affect MSCs given their adherence, an LP-1 cell suspension [16] was used in this experiment. To increase the probability of 


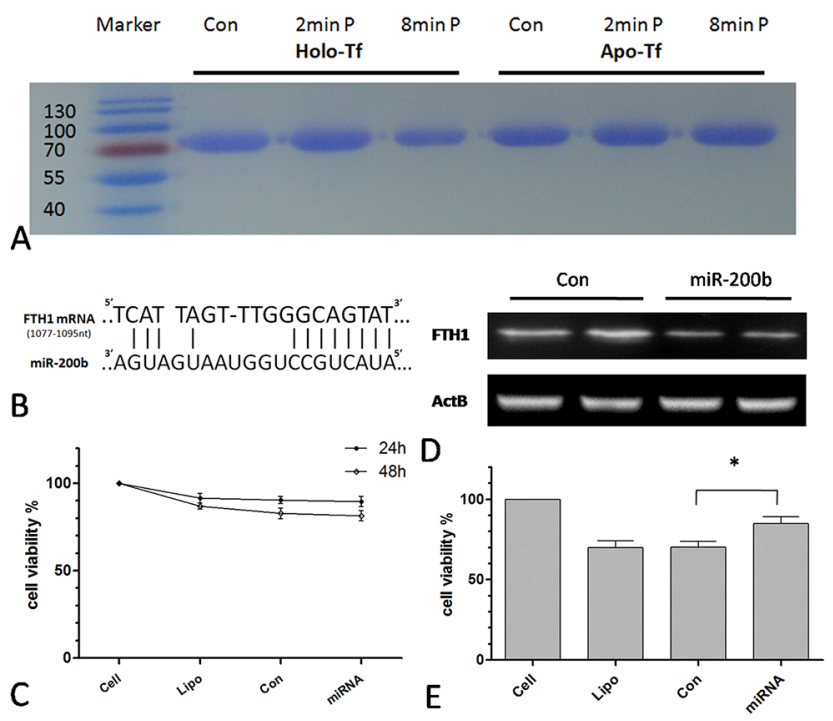

Fig 7. Decreased sensitivity to plasma by knockdown of iron protein expression. (A) Gel electrophoresis of holo- and apo-transferrin treated with Ar plasma for 2 or $8 \mathrm{~min}$. (B) Sequences of miR-200b and the complementary site in the FTH1 gene. (C) Viability of MSCs transfected with control miRNA or miR$200 \mathrm{~b}$ for 24 or $48 \mathrm{~h}$. (D) FTH1 expression in MSCs transfected for $48 \mathrm{~h}$, as determined by western blotting. (E) Viability of transfected MSCs $24 \mathrm{~h}$ after $20 \mathrm{~s}$ of Ar plasma treatment. ${ }^{*} \mathrm{P}<0.05$. Lipo indicates that only the transfection agent (Lipofectamine 2000) was added to cells.

doi:10.1371/journal.pone.0128205.g007

interaction between $\mathrm{OH}$ and LP-1 cells, the cells were treated with $\mathrm{He}+\mathrm{H}_{2} \mathrm{O}$ or Ar plasma for $20 \mathrm{~s}$ at a relatively high concentration $\left(5 \times 10^{6} / \mathrm{ml}\right)$. Fe(III)-EDTA $(1 \mu \mathrm{M})$ had no effect on cell viability by itself, but enhanced plasma-induced cell death (Fig 8A). This was confirmed by flow cytometry in which apoptotic cells were visualized by annexin V-FITC and PI staining (Fig 8B).
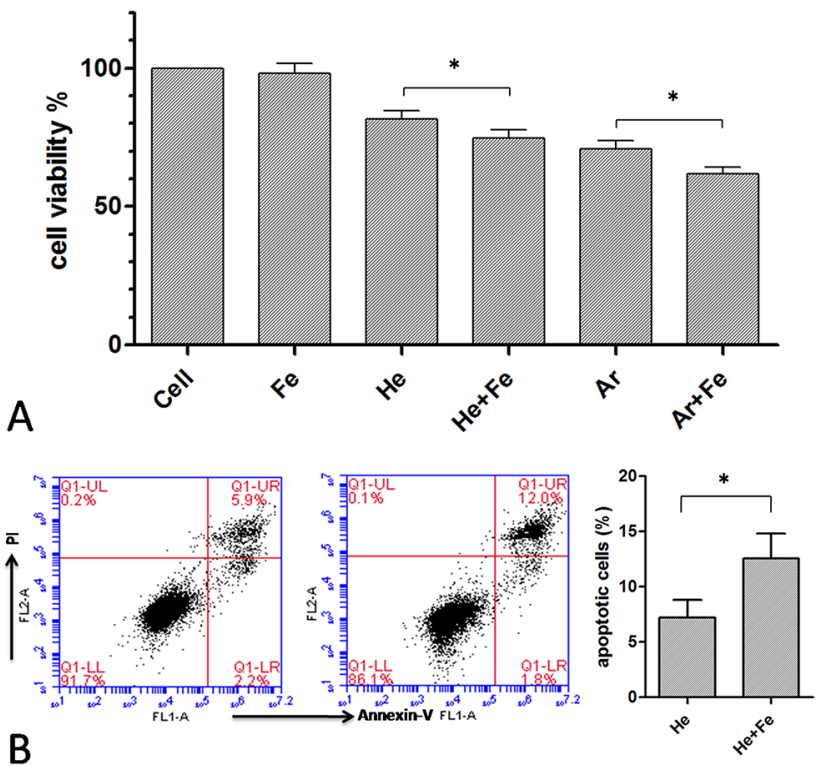

Fig 8. Iron enhances plasma-induced cell death. (A) Viability and (B) apoptosis of LP-1 cells $24 \mathrm{~h}$ after a $20-\mathrm{s} \mathrm{He}+\mathrm{H}_{2} \mathrm{O}$ or Ar plasma treatment in the presence of $\mathrm{Fe}\left(\right.$ III)-EDTA. ${ }^{*} \mathrm{P}<0.05$.

doi:10.1371/journal.pone.0128205.g008 


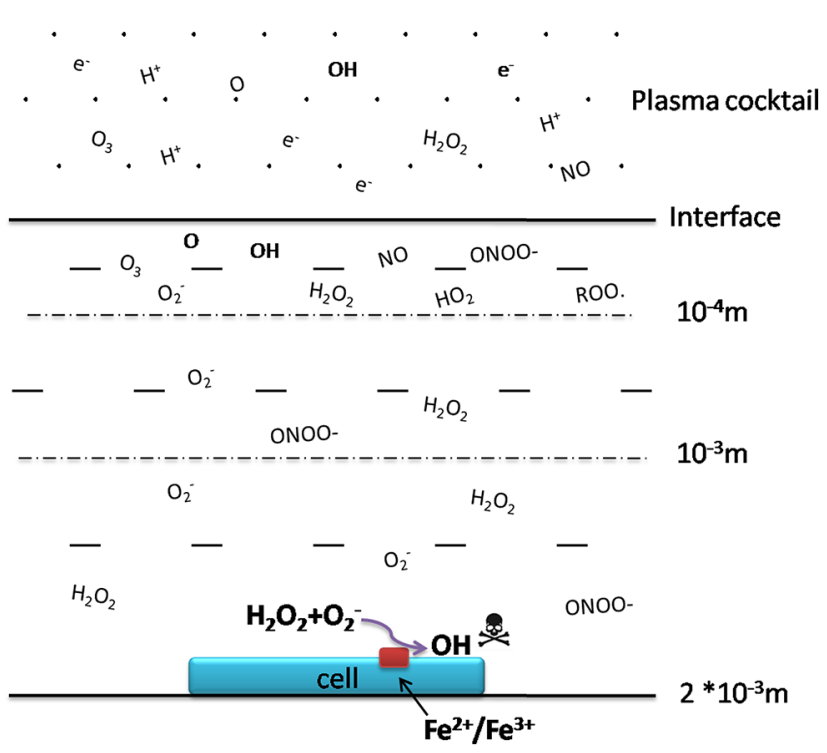

Fig 9. Model for a plasma-treated cell system and the mechanism of in situ $\mathrm{OH}$ generation.

doi:10.1371/journal.pone.0128205.g009

CAP can produce various reactive species such as the $\mathrm{OH}$ radical, which is the most highly reactive and can damage most macromolecules including DNA, proteins, lipids, or polysaccharides. $\mathrm{OH}$ is 100 fold more potent than $\mathrm{H}_{2} \mathrm{O}_{2}$ and $\mathrm{O}_{2}{ }^{-}$and can affect molecules located a few nanometers from its site of generation [40]. However, given its high reactivity, $\mathrm{OH}$ has an extremely short half-life (in the nanosecond range). Thus, although CAP can generate $\mathrm{OH}$ radicals at $\mu \mathrm{M}$ concentrations, these species are unlikely to reach cells and cause damage to biomolecules; this can only be achieved by long-lived $\mathrm{H}_{2} \mathrm{O}_{2}$ species [41, 42]. As such, it is debatable whether plasma medicine constitutes nothing more than $\mathrm{H}_{2} \mathrm{O}_{2}$ treatment. The present study showed for the first time that two major reactive species $-\mathrm{H}_{2} \mathrm{O}_{2}$ and $\mathrm{O}_{2}{ }^{-}-$can penetrate to a depth that is sufficient to reach cells; we also propose a novel model of in situ generation of $\mathrm{OH}$, which acts as the final effector causing cellular damage (Fig 9). This model can explain why treating cells with $\mathrm{H}_{2} \mathrm{O}_{2}$ or $\mathrm{O}_{2}^{-}$scavengers can reverse the biological effects of plasma treatment while treatment with an $\mathrm{OH}$ scavenger had little effect. The model also highlights the synergy between $\mathrm{H}_{2} \mathrm{O}_{2}$ and $\mathrm{O}_{2}{ }^{-}$at relatively low concentrations (compared to their respective lethal doses). Under physiological conditions, $\mathrm{H}_{2} \mathrm{O}_{2}$ and $\mathrm{O}_{2}{ }^{-}$concentrations are rarely low-estimates for $\mathrm{O}_{2}^{-}$within the mitochondrial matrix are in the range 10-200 pM [43]and therefore the iron-catalyzed Haber-Weiss reaction has a negligible effect on cells. However, in a plasma-treated cell system, the plasma provides high levels of both $\mathrm{H}_{2} \mathrm{O}_{2}$ and $\mathrm{O}_{2}{ }^{-}$, with iron-catalyzed $\mathrm{OH}$ production thereby greatly influencing cell viability. These findings provide a basis for achieving optimal biological effects by plasma treatment using this in situ mechanism for $\mathrm{OH}$ generation.

\section{Conclusion}

In conclusion, the present study demonstrated for the first time by biological experiments that $\mathrm{H}_{2} \mathrm{O}_{2}$ and $\mathrm{O}_{2}{ }^{-}$are the two major reactive species that are produced by plasma treatment. Given that the concentration of either species is insufficient to induce cell death, we propose that the $\mathrm{OH}$ radical generated in situ of the cells by the Haber-Weiss reaction ultimately causes cell damage and death. 


\section{Supporting Information}

S1 Fig. Experimental setup for plasma treatment. The apparatus consisted of a gas flow controller, high-voltage power supply, oscilloscope, and plasma jet.

(TIF)

\section{Acknowledgments}

The authors thank Tian Miao and Qiaosong Li for technical assistance.

\section{Author Contributions}

Conceived and designed the experiments: DX D. Liu MGK. Performed the experiments: DX BW CC. Analyzed the data: DX D. Liu D. Li MGK. Contributed reagents/materials/analysis tools: ZC YY HC. Wrote the paper: DX.

\section{References}

1. Kong MG, Kroesen G, Morfill G, Nosenko T, Shimizu T, Van Dijk J, et al. Plasma medicine: an introductory review. New Journal of Physics. 2009; 11(11):115012.

2. Brun $P$, Brun $P$, Vono $M$, Venier $P$, Tarricone $E$, Deligianni V, et al. Disinfection of Ocular Cells and Tissues by Atmospheric-Pressure Cold Plasma. Plos One. 2012; 7(3). doi: ARTN e33245 doi: 10.1371/ journal.pone.0033245 PMID: WOS:000303198600050.

3. Keidar M, Shashurin A, Volotskova O, Stepp MA, Srinivasan P, Sandler A, et al. Cold atmospheric plasma in cancer therapy. Physics Of Plasmas. 2013; 20(5). doi: Artn 057101 doi: 10.1063/1.4801516 PMID: WOS:000320000000118.

4. Plewa JM, Yousfi M, Frongia C, Eichwald O, Ducommun B, Merbahi N, et al. Low-temperature plasmainduced antiproliferative effects on multi-cellular tumor spheroids. New Journal Of Physics. 2014; 16. doi: Artn 043027 doi: 10.1088/1367-2630/16/4/043027 PMID: WOS:000335383100003.

5. Graves DB. Reactive Species from Cold Atmospheric Plasma: Implications for Cancer Therapy. Plasma Processes And Polymers. 2014; 11(12):1120-7. doi: 10.1002/ppap.201400068 PMID: WOS:000346034700002.

6. Graves DB. The emerging role of reactive oxygen and nitrogen species in redox biology and some implications for plasma applications to medicine and biology. J Phys D Appl Phys. 2012; 45(26). doi: Artn 263001 doi: 10.1088/0022-3727/45/26/263001 PMID: WOS:000305418900001.

7. Ahn HJ, Kim KI, Hoan NN, Kim CH, Moon E, Choi KS, et al. Targeting Cancer Cells with Reactive Oxygen and Nitrogen Species Generated by Atmospheric-Pressure Air Plasma. Plos One. 2014; 9(1). doi: ARTN e86173 doi: 10.1371/journal.pone.0086173 PMID: WOS:000330244500198.

8. Keidar M, Shashurin A, Volotskova O, Stepp MA, Srinivasan P, Sandler A, et al. Cold atmospheric plasma in cancer therapy. Physics of Plasmas. 2013; 20:057101.

9. Wende K, Strassenburg S, Haertel B, Harms M, Holtz S, Barton A, et al. Atmospheric pressure plasma jet treatment evokes transient oxidative stress in $\mathrm{HaCaT}$ keratinocytes and influences cell physiology. Cell Biol Int. 2014; 38(4):412-25. doi: 10.1002/cbin.10200 PMID: 24155089.

10. Chen C, Liu D, Liu Z, Yang A, Chen H, Shama G, et al. A Model of Plasma-Biofilm and Plasma-Tissue Interactions at Ambient Pressure. Plasma Chemistry and Plasma Processing. 2014; 34(3):403-41.

11. Yusupov M, Neyts EC, Simon P, Berdiyorov G, Snoeckx R, van Duin ACT, et al. Reactive molecular dynamics simulations of oxygen species in a liquid water layer of interest for plasma medicine. J Phys $D$ Appl Phys. 2014; 47(2). doi: Artn 025205 doi: 10.1088/0022-3727/47/2/025205 PMID: WOS:000329108000013.

12. Tian $\mathrm{W}$, Kushner MJ. Atmospheric pressure dielectric barrier discharges interacting with liquid covered tissue. J Phys D Appl Phys. 2014; 47(16). doi: Artn 165201 doi: 10.1088/0022-3727/47/16/165201 PMID: WOS:000333745000005.

13. Tani A, Ono Y, Fukui S, Ikawa S, Kitano K. Free radicals induced in aqueous solution by non-contact atmospheric-pressure cold plasma. Applied Physics Letters. 2012; 100(25). doi: Artn 254103 doi: 10. 1063/1.4729889 PMID: WOS:000305676400111.

14. Kanazawa S, Furuki T, Nakaji T, Akamine S, Ichiki R. Measurement of OH Radicals in Aqueous Solution Produced by Atmospheric-pressure LF Plasma Jet. Department of electrical and electronic engineering, Oita University, Japan. 
15. Tresp H, Hammer MU, Weltmann K-D, Reuter S. EFFECTS OF ATMOSPHERE COMPOSITION AND LIQUID TYPE ON PLASMA GENERATED REACTIVE SPECIES IN BIOLOGICALLY. PlasmaMed. 2014; doi: 10.1615/PlasmaMed.2014009711 doi: Doi 10.1021/Ja00242a038. PMID: WOS: A1987G942100038.

16. Xu D, Hu J, Xu S, De Bruyne E, Menu E, Van Camp B, et al. Dll1/Notch activation accelerates multiple myeloma disease development by promoting CD138+ MM-cell proliferation. Leukemia. 2012; 26 (6):1402-5. doi: 10.1038/leu.2011.332 PMID: 22094583.

17. http://www.lifetechnologies.com/cn/zh/home/references/molecular-probes-the-handbook/tables/ scavengers-of-reactive-oxygen-species.html.

18. Franco R, Panayiotidis MI, Cidlowski JA. Glutathione depletion is necessary for apoptosis in lymphoid cells independent of reactive oxygen species formation. J Biol Chem. 2007; 282(42):30452-65. doi: 10 1074/jbc.M703091200 PMID: WOS:000250136300013.

19. Nicolescu AC, Li Q, Brown L, Thatcher GRJ. Nitroxidation, nitration, and oxidation of a BODIPY fluorophore by RNOS and ROS. Nitric Oxide-Biol Ch. 2006; 15(2):163-76. doi: 10.1016/j.niox.2006.01.010 PMID: WOS:000240007300009.

20. Peden DB, Swiersz M, Ohkubo K, Hahn B, Emery B, Kaliner MA. Nasal secretion of the ozone scavenger uric acid. The American review of respiratory disease. 1993; 148(2):455-61. doi: 10.1164/ajrccm/ 148.2.455 PMID: 8342911.

21. Bleeke T, Zhang H, Madamanchi N, Patterson C, Faber JE. Catecholamine-induced vascular wall growth is dependent on generation of reactive oxygen species. Circulation research. 2004; 94(1):3745. doi: 10.1161/01.Res.0000109412.80157.7d PMID: WOS:000187911700010.

22. Chen C, Liu DX, Liu ZC, Yang AJ, Chen HL, Shama G, et al. A Model of Plasma-Biofilm and PlasmaTissue Interactions at Ambient Pressure. Plasma Chemistry And Plasma Processing. 2014; 34(3):40341. doi: 10.1007/s11090-014-9545-1 PMID: WOS:000334434800004.

23. Fenton. HJH. Oxidation of tartaric acid in presence of iron. J Chem Soc. 1894; 65(899). PMID: WOS: A1986AYT7800017.

24. Prousek J. Fenton chemistry in biology and medicine. Pure And Applied Chemistry. 2007; 79 (12):2325-38. doi: 10.1351/pac200779122325 PMID: WOS:000251582100019.

25. Chen SX, Schopfer P. Hydroxyl-radical production in physiological reactions-A novel function of peroxidase. Eur J Biochem. 1999; 260(3):726-35. doi: 10.1046/j.1432-1327.1999.00199.x PMID: WOS:000079371200017.

26. Kehrer JP. The Haber-Weiss reaction and mechanisms of toxicity. Toxicology. 2000; 149(1):43-50. doi: 10.1016/S0300-483x(00)00231-6 PMID: WOS:000089076700006.

27. Koppenol WH. The Haber-Weiss cycle-71 years later. Redox Rep. 2002; 7(1):59-60. doi: 10.1179/ 135100002125000208 PMID: WOS:000175312500011.

28. Blanksby SJ, Bierbaum VM, Ellison GB, Kato S. Superoxide does react with peroxides: Direct observation of the haber-weiss reaction in the gas phase. Angew Chem Int Edit. 2007; 46(26):4948-50. doi: 10. 1002/anie.200700219 PMID: WOS:000247773300019.

29. Wu XN, Su D, Wang L, Yu FL. Roles of the hepcidin-ferroportin axis and iron in cancer. Eur J Cancer Prev. 2014; 23(2):122-33. doi: 10.1097/Cej.0b013e3283627f14 PMID: WOS:000331290300008.

30. Wang Q, Zhou J, Zhong DW, Wang QW, Huang JS. Ferroportin in the progression and prognosis of hepatocellular carcinoma. Eur J Med Res. 2013; 18. doi: Artn 59 doi: 10.1186/2047-783x-18-59 PMID: WOS:000330075300001.

31. Suzuki YA, Lopez V, Lonnerdal B. Mammalian lactoferrin receptors: structure and function. Cellular and molecular life sciences: CMLS. 2005; 62(22):2560-75. doi: 10.1007/s00018-005-5371-1 PMID: 16261254.

32. Li Y, Guan Q, Chen Y, Han H, Liu W, Nie Z. Transferrin receptor and ferritin-H are developmentally regulated in oligodendrocyte lineage cells. Neural regeneration research. 2013; 8(1):6-12. doi: 10.3969/j. issn.1673-5374.2013.01.001 PMID: 25206366; PubMed Central PMCID: PMC4107500.

33. Luck AN, Bobst CE, Kaltashov IA, Mason AB. Human serum transferrin: is there a link among autism, high oxalate levels, and iron deficiency anemia? Biochemistry-Us. 2013; 52(46):8333-41. doi: 10.1021/ bi401190m PMID: 24152109; PubMed Central PMCID: PMC3887466.

34. Garrick MD, Dolan KG, Horbinski C, Ghio AJ, Higgins D, Porubcin M, et al. DMT1: a mammalian transporter for multiple metals. Biometals: an international journal on the role of metal ions in biology, biochemistry, and medicine. 2003; 16(1):41-54. PMID: 12572663.

35. Andrews NC. The iron transporter DMT1. Int J Biochem Cell B. 1999; 31(10):991-4. doi: 10.1016/ S1357-2725(99)00065-5 PMID: WOS:000083325100002. 
36. Lortz S, Schroter S, Stuckemann V, Mehmeti I, Lenzen S. Influence of cytokines on Dmt1 iron transporter and ferritin expression in insulin-secreting cells. Journal of molecular endocrinology. 2014; 52 (3):301-10. doi: 10.1530/JME-13-0261 PMID: 24850829.

37. Al-Qenaei A, Yiakouvaki A, Reelfs O, Santambrogio P, Levi S, Hall ND, et al. Role of intracellular labile iron, ferritin, and antioxidant defence in resistance of chronically adapted Jurkat T cells to hydrogen peroxide. Free radical biology \& medicine. 2014; 68:87-100. doi: 10.1016/j.freeradbiomed.2013.12.006 PMID: 24333634; PubMed Central PMCID: PMC4046229.

38. Brieland JK, Fantone JC. Ferrous Iron Release From Transferrin by Human Neutrophil-Derived Superoxide Anion-Effect Of Ph And Iron Saturation. Arch Biochem Biophys. 1991; 284(1):78-83. doi: 10. 1016/0003-9861(91)90266-L PMID: WOS:A1991ER53100014.

39. Shpyleva SI, Tryndyak VP, Kovalchuk O, Starlard-Davenport A, Chekhun VF, Beland FA, et al. Role of ferritin alterations in human breast cancer cells. Breast cancer research and treatment. 2011; 126 (1):63-71. doi: 10.1007/s10549-010-0849-4 PMID: 20390345.

40. Hippeli S, Elstner EF. OH-radical-type reactive oxygen species: a short review on the mechanisms of $\mathrm{OH}$-radical- and peroxynitrite toxicity. Zeitschrift fur Naturforschung C, Journal of biosciences. 1997; 52 (9-10):555-63. PMID: 9373992.

41. Yi Y, Zhou J, Guo H, Zhao J, Su J, Wang L, et al. Safe direct synthesis of high purity $\mathrm{H} 2 \mathrm{O} 2$ through a H2/O2 plasma reaction. Angew Chem Int Ed Engl. 2013; 52(32):8446-9. doi: 10.1002/anie.201304134 PMID: 23804306.

42. Bekeschus S, Kolata J, Winterbourn C, Kramer A, Turner R, Weltmann KD, et al. Hydrogen peroxide: A central player in physical plasma-induced oxidative stress in human blood cells. Free Radic Res. 2014; 48(5):542-9. doi: 10.3109/10715762.2014.892937 PMID: 24528134.

43. Cadenas E, Davies KJA. Mitochondrial free radical generation, oxidative stress, and aging. Free Radical Bio Med. 2000; 29(3-4):222-30. doi: 10.1016/S0891-5849(00)00317-8 PMID: WOS:000089535700004. 